\title{
MOCVD of crystalline $\mathrm{Bi}_{2} \mathrm{O}_{3}$ thin films using a single-source bismuth alkoxide precursor and their use in photodegradation of water
}

\author{
Savio J. A. Moniz, Christopher S. Blackman,* Claire J. Carmalt, and Geoffrey Hyett \\ Materials Chemistry Centre, Department of Chemistry, University College London, 20 Gordon Street, London \\ 5 WCIH OAJ, UK.
}

Email: c.blackman@ucl.ac.uk, Tel: +44(0)2076794703

Received (in $X X X, X X X)$ Xth $X X X X X X X X X 200 X$, Accepted Xth $X X X X X X X X X 200 X$

First published on the web Xth $X X X X X X X X X 200 X$

DOI: 10.1039/b000000x

10

Bismuth (III) tert-butoxide $\left[\mathrm{Bi}\left(\mathrm{O}^{t} \mathrm{Bu}\right)_{3}\right]$ was utilised as a single-source precursor to controllably deposit thin films of different phases of bismuth oxide $\left(\mathrm{Bi}_{2} \mathrm{O}_{3}\right)$ on glass substrates via low-pressure chemical vapour deposition (LPCVD). Band gaps for the different phases have been measured $\left(E_{g}=2.3-3.0 \mathrm{eV}\right)$ and the films displayed excellent photodegradation of water under near-UV irradiation.

\section{Introduction}

Bismuth oxide $\left(\mathrm{Bi}_{2} \mathrm{O}_{3}\right)$ is an important component of several ferroelectric, ${ }^{1}$ multiferroic ${ }^{2,3}$ and superconducting oxide materials. ${ }^{4}$ It has also received much interest due to its use as an ion conducting electrolyte material in solid oxide fuel cells, ${ }^{5}$ an electrode material in discriminating gas sensors ${ }^{6}$ and as an effective UV light photocatalyst. ${ }^{7,8}$ There are a number of distinct crystallographic phases $(\alpha, \beta, \gamma, \delta, \omega)$ of $\mathrm{Bi}_{2} \mathrm{O}_{3}$ that have been 20 reported; the low temperature $\alpha$ - and high temperature $\delta$ - phases are stable whilst the others are metastable. ${ }^{9}$

There is a driving force for the investigation of new cheap, clean and reliable energy sources that have limited environmental impact to meet global demand for energy. Solar energy, in conjunction with a photocatalyst, may be used in order to generate a chemical fuel source (hydrogen) via photochemical reduction of water. The most common materials used for photochemical water splitting are transition metal oxides with $\mathrm{d}^{0}$ electron 25 configurations, i.e. $\mathrm{TiO}_{2}$, whose band-gaps (typically $3.0 \mathrm{eV}$ and above) are too high to serve as efficient water splitting photocatalysts under solar irradiation. $\mathrm{Bi}_{2} \mathrm{O}_{3}$ possesses band-gap values of $2.29-3.31 \mathrm{eV}$ depending on the crystalline phase; the optical gap of $\mathrm{BiO}$ has been determined to be as high as $3.31 \mathrm{eV}, \alpha-\mathrm{Bi}_{2} \mathrm{O}_{3}$ to be 2.85 $\mathrm{eV}^{11}$ and the amorphous phase as low as $\left.2.0 \mathrm{eV}\right) .{ }^{9}$ These values indicate the potential of $\mathrm{Bi}_{2} \mathrm{O}_{3}$ to serve as a photocatalyst under solar irradiation, and the photocatalytic activities of undoped $\alpha$ - $\beta$ - and $\delta-\mathrm{Bi}_{2} \mathrm{O}_{3}$ have been

30 demonstrated during degradation of model pollutant dyes Rhodamine $\mathrm{B}^{7,10}$ and methylene orange, ${ }^{11}$ whilst transition metal doped $\gamma-\mathrm{Bi}_{2} \mathrm{O}_{3}$ nanoparticles have been shown to photocatalytically split water. ${ }^{8}$

Bismuth oxide films have previously been grown by CVD in dual-source reactions with oxygen and triphenylbismuth, $\left[\mathrm{Bi}\left(\mathrm{C}_{6} \mathrm{H}_{5}\right)_{3}\right]$. $\left[\mathrm{Bi}\left(\mathrm{C}_{6} \mathrm{H}_{5}\right)_{3}\right]$ is the most commonly used CVD precursor due to its low air and moisture sensitivity ${ }^{12}$ and it has been the subject of numerous studies concerning its deposition characteristics 
and mechanism of transport in the gas phase using in-situ FTIR spectroscopy. ${ }^{13}$ Similarly $\left[\mathrm{Bi}(\mathrm{o}-\mathrm{tol})_{3}\right]$ and $[\mathrm{Bi}(\mathrm{p}$ tol $)_{3}$ ] have been shown to be useful bismuth precursors for growth of bismuth oxide films. ${ }^{14}$ However, the high thermal stability of these precursors requires high deposition temperatures and carbon contamination can be problematic. Trimethylbismuth has been shown to deposit $\alpha-\mathrm{Bi}_{2} \mathrm{O}_{3}$ films in a dual source reaction with 5 oxygen, ${ }^{15,16}$ however trimethylbismuth is pyrophoric and requires cooling prior to and during deposition.

In general, the availability of volatile single-source bismuth oxide precursors for CVD is extremely limited. To overcome the problems of precursor volatility and high deposition temperatures new single-source precursors are required to deposit phase-pure $\mathrm{Bi}_{2} \mathrm{O}_{3}$ films. The basic requirements for incorporation of oxygen into the molecule using sterically bulky ligands to limit oligomerisation have led to the development of three main types 10 of oxygen-containing precursor:

Alkoxides, $\left[\mathrm{M}(\mathrm{OR})_{3}\right], \mathrm{R}=$ alkyl, aryl, $\mathrm{OR}$ (donor functionalised), $\mathrm{CX}_{3}(\mathrm{X}=$ halogen $)$

Beta-diketonates, $\left[\mathrm{M}\left(\mathrm{R}^{1} \mathrm{COCHCOR}^{2}\right)_{3}\right], \mathrm{R}=$ alkyl, aryl, $\mathrm{CX}_{3}(\mathrm{X}=$ halogen $)$

Carboxylates, $\left[\mathrm{M}\left(\mathrm{O}_{2} \mathrm{CR}\right)_{3}\right], \mathrm{R}=$ alkyl, aryl, $\mathrm{CX}_{3}(\mathrm{X}=$ halogen $)$

15

Alkoxides of bismuth appear to exhibit a common problem of poor solubility and poor volatility and to date there appears to be only two bismuth alkoxides in the literature that have been used for $\mathrm{CVD}$. $\left[\mathrm{Bi}\left(\mathrm{OCMe}_{2} \mathrm{Et}\right)_{3}\right]$ and $\left[\mathrm{Bi}\left(\mathrm{OCMe}_{2} \mathrm{CH}_{2} \mathrm{OMe}\right)_{3}\right]$ (also known as $\left[\mathrm{Bi}(\mathrm{mmp})_{3}\right]$ ) have both been used as the bismuth source for deposition of $\mathrm{SrBi}_{2} \mathrm{Ta}_{2} \mathrm{O}_{9}$ films. Jones and co-workers reported the crystal structure of $\left[\mathrm{Bi}(\mathrm{mmp})_{3}\right]$ as 20 monomeric and gave a description of its use in the MOCVD of bismuth oxide with oxygen as the reactive gas using Direct Liquid Injection CVD (DLI-CVD) ${ }^{17}$ The use of $\left[\mathrm{Bi}\left(\mathrm{O}^{t} \mathrm{Bu}\right)_{3}\right]$ has been suggested for Atomic Layer Deposition (ALD) of bismuth oxide but proved unsuccessful in this methodology. ${ }^{18}$

Similarly, there is little mention of the use of bismuth $\beta$-diketonates for CVD and the most common example is that of bismuth tetramethylheptanedionate, $\left(\left[\mathrm{Bi}(\mathrm{thd})_{3}\right]\right.$ or $\left.\left[\mathrm{Bi}(\mathrm{dpm})_{3}\right]\right)$, which has a lower decomposition 25 temperature than alkylbismuth and bismuth halide compounds, but possesses poor thermal stability upon sublimation. Kang ${ }^{19}$ used DLI-CVD of $\left[\mathrm{Bi}(\text { thd })_{3}\right]$ to deposit amorphous $\mathrm{Bi}_{2} \mathrm{O}_{3}$ on silicon substrates at temperatures between $240-435{ }^{\circ} \mathrm{C}$, using an oxygen gas co-reactant.

Bismuth silyl amide $\left[\mathrm{Bi}\left(\mathrm{N}\left(\mathrm{SiMe}_{3}\right)_{2}\right]_{3}\right.$ has been used in conjunction with $\mathrm{H}_{2} \mathrm{O}$ to produce $\mathrm{BiO}_{\mathrm{x}}$ films via Atomic Layer Deposition (ALD). ${ }^{20}$ The ease of synthesis, excellent solubility and relative ease of sublimation of $30\left[\mathrm{Bi}\left(\mathrm{N}\left(\mathrm{SiMe}_{3}\right)_{2}\right]_{3}\right.$ led to its use as an ALD precursor, however poor reproducibility in deposition of the binary oxide phase was encountered. It was also suggested that the use of more reactive di-oxygen instead of $\mathrm{H}_{2} \mathrm{O}$ would lead to deposition of bismuth silicate films. 
In all examples of CVD of crystalline $\mathrm{Bi}_{2} \mathrm{O}_{3}$ films, oxygen gas or plasma was required during depositions; the use of $\left[\mathrm{Bi}(\mathrm{mmp})_{3}\right]$ as a single-source precursor has been briefly mentioned, but no details regarding crystalline phase(s) obtained were given in the paper. ${ }^{17}$

We have investigated the decomposition characteristics of $\left[\mathrm{Bi}\left(\mathrm{O}^{t} \mathrm{Bu}\right)_{3}\right],\left[\mathrm{Bi}(\mathrm{mmp})_{3}\right]$ and $\left[\mathrm{Bi}(\text { thd })_{3}\right]$ by coupled 5 mass spectrometry-thermal gravimetric analysis-differential scanning calorimetry (MS-TGA-DSC) in order to identify suitable deposition conditions and to understand the decomposition pathway of the precursors. The sublimation characteristics of $\left[\mathrm{Bi}\left(\mathrm{O}^{t} \mathrm{Bu}\right)_{3}\right]$ suggest that it is suitably volatile at relatively mild temperatures and pressures to be used as a solid-state precursor for LPCVD, with the sterically demanding $\mathrm{O}^{t} \mathrm{Bu}$ groups inhibiting oligomerization, enhancing volatility (it has been shown to be monomeric in the gas phase) ${ }^{21}$ and the

10 decomposition characteristics indicate clean decomposition to $\mathrm{Bi}_{2} \mathrm{O}_{3}$. We present the first use of a single-source bismuth alkoxide precursor, $\left[\mathrm{Bi}\left(\mathrm{O}^{t} \mathrm{Bu}\right)_{3}\right]$, for phase selective deposition of crystalline $\mathrm{Bi}_{2} \mathrm{O}_{3}$ thin films using LPCVD, utilising a range of substrate temperatures, system pressures and carrier gas flow rates. The films obtained were fully characterised, and we have investigated for the first time, $\mathrm{Bi}_{2} \mathrm{O}_{3}$ films grown by CVD for photodegradation of water.

\section{EXPERIMENTAL}

\section{General Procedures}

All reactions were performed under a dry, oxygen-free nitrogen atmosphere using standard Schlenk techniques and an Mbraun Unilab glove box. Nitrogen (99.96\%) was obtained from BOC and used as supplied. All 20 reagents were used without further purification, and were procured from Sigma Aldrich or Alfa Aesar Ltd. CVD experiments were performed using a horizontal cold wall CVD reactor which has previously been detailed elsewhere. ${ }^{22}$ The pressure of the reactor and inlet gas flows were regulated using mechanical throttle valves. Nitrogen was used as a carrier gas. The substrate temperature was varied between $425-500{ }^{\circ} \mathrm{C}$, and the bubbler temperature maintained at $110{ }^{\circ} \mathrm{C}$. Depositions were carried out for $1 \mathrm{~h}$ on $30 \mathrm{~mm} \mathrm{x} 15 \mathrm{~mm}$ borosilicate 25 glass slides, and approximately $150 \mathrm{mg}$ of fresh precursor was used for each deposition.

\section{Physical Measurements}

Coupled mass spectrometry - thermal gravimetric analysis - differential scanning calorimetry (MS-TGA-DSC) was performed using a Netzsch STA 449C instrument. The TGA was carried out in sealed aluminium pans, 30 pierced with a small hole just prior to analysis, at atmospheric pressure, under a flow of helium gas (50 $\mathrm{cm}^{3} / \mathrm{min}$ ). The rate of heating was $10{ }^{\circ} \mathrm{C} \mathrm{min}^{-1}$. Grazing incidence $\left(5^{\circ}\right)$ powder X-ray diffraction (XRD) was carried out on a Bruker AXS D8 Discover machine using monochromatic $\mathrm{Cu}-\mathrm{K}_{\alpha}$ radiation $\left(\lambda_{1}=1.54 \AA\right.$ ), with phase information obtained via the EVA suite of programs (version 2). Scanning electron microscope (SEM) images were obtained on a JSM-6301F Scanning Microscope Field Emission machine after coating samples 
with an ultrathin layer of gold (not observed in images) to avoid charging. UV-Vis spectra were recorded in transmission mode over the range 175-2500 nm using a Perkin Elmer Lambda 950 photospectrometer. Raman spectra were acquired using a Renishaw Raman System 1000 using a helium-neon laser wavelength of $515 \mathrm{~nm}$. XPS spectra were obtained using a Kratos AXIS Ultra machine with a Delay line detector. A monochromated

$5 \mathrm{Al}-\mathrm{K}_{\alpha} \mathrm{X}$-ray source producing a FWHM on the $\mathrm{Ag} 3 \mathrm{~d}_{5 / 2}$ peak of $0.48 \mathrm{eV}$ was used. A chamber pressure of $7 \mathrm{x}$ $10^{-9}$ torr was maintained during the scans. The samples were earthed using copper clips to prevent charging, and were etched for 10 mins at $4 \mathrm{kV}$. Spectra were fitted using CasaXPS version 2.3.15. Full width at half maximum (FHWMs) were constrained between $0.9-1.3$ for $\mathrm{Bi} 4 \mathrm{f}$, and its peak position constrained between $153.9-168 \mathrm{eV}$. For O 1s, the FWHM was constrained between $1.3-1.7$ and its position limited between 524.7 $10-543 \mathrm{eV}$.

\section{Synthesis}

$\left[\mathrm{Bi}\left(\mathrm{O}^{t} \mathrm{Bu}\right)_{3}\right]$ was synthesised according to the literature in $82 \%$ yield. ${ }^{18,23}$ Tris(1-methoxy-2-methyl-2propanolato)bismuth(III), $\left\{\left[\mathrm{Bi}(\mathrm{mmp})_{3}\right]\right\}$, was synthesised according to a literature procedure via an alcohol15 amine exchange in 58\% yield, and possessed identical ${ }^{1} \mathrm{H}$ NMR, ${ }^{13} \mathrm{C}$ NMR, infrared and microanalytical data. $^{17,24}\left[\mathrm{Bi}(\text { thd })_{3}\right]$ was synthesised from a modified version of the literature preparation from $\left[\mathrm{Bi}\left(\mathrm{N}\left(\mathrm{SiMe}_{3}\right)_{2}\right]_{3}\right.$ and the free ligand (Hthd) in $76 \%$ yield, and possessed identical ${ }^{1} \mathrm{H}$ NMR, ${ }^{13} \mathrm{C}$ NMR, infrared and microanalytical data to those published. ${ }^{18,23}$

\section{RESULTS}

The decomposition profiles of $\left[\mathrm{Bi}(\mathrm{mmp})_{3}\right],\left[\mathrm{Bi}(\mathrm{thd})_{3}\right]$ and $\left[\mathrm{Bi}\left(\mathrm{O}^{t} \mathrm{Bu}\right)_{3}\right]$ were examined by coupled MS-TGADSC under a helium atmosphere (Figure 1). 


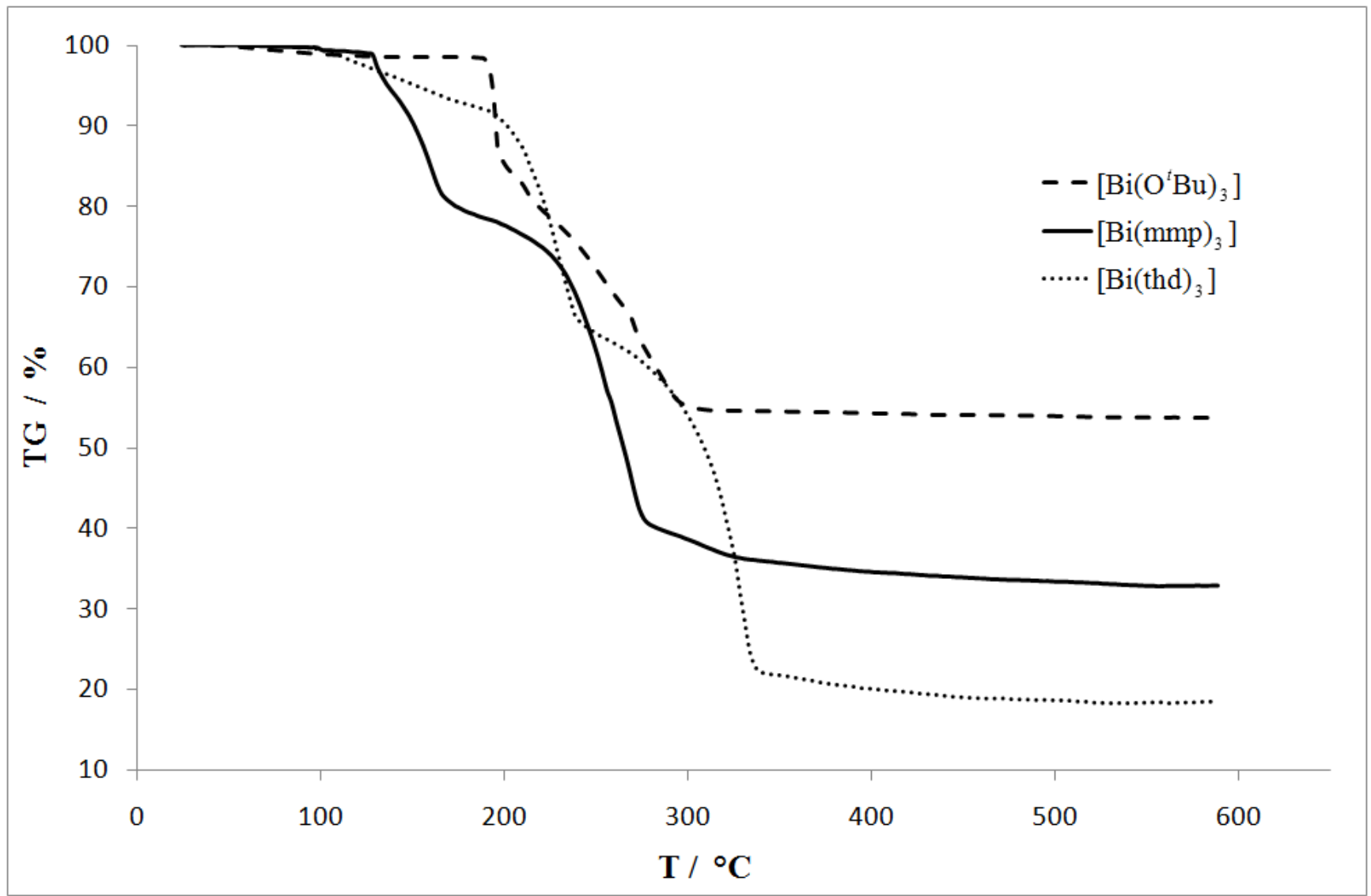

Figure 1 - TGA patterns of $\left[\mathrm{Bi}(\mathrm{mmp})_{3}\right],\left[\mathrm{Bi}(\text { thd })_{3}\right]$ and $\left[\mathrm{Bi}\left(\mathrm{O}^{t} \mathrm{Bu}\right)_{3}\right]$

The TGA data of $\left[\mathrm{Bi}(\mathrm{mmp})_{3}\right]$ shows a negligible weight loss $(1.1 \%)$ up to $129{ }^{\circ} \mathrm{C}$, most likely due to excess 5 solvent molecules remaining after synthesis, and may be ignored. An endotherm is observed in the DSC trace (not shown) at $130{ }^{\circ} \mathrm{C}$, which is assigned as the melting point of $\left[\mathrm{Bi}(\mathrm{mmp})_{3}\right]$, and this is followed by the first steep weight loss of $18.3 \%$ up to $171^{\circ} \mathrm{C}$ which is attributed to volatilisation of the precursor. Subsequent weight loss of $39.8 \%$ is observed between 171 and $279{ }^{\circ} \mathrm{C}$, which is coincident with an exotherm in the DSC (not shown) and is therefore attributed to decomposition of the precursor. Between $280{ }^{\circ} \mathrm{C}$ and the end of the TGA 10 experiment $\left(600{ }^{\circ} \mathrm{C}\right)$, there was a small weight loss of $7.7 \%$. The fraction of weight loss observed during the decomposition of the precursor is $\sim 50 \%$ ( $40 \%$ total mass loss from a total mass of $80 \%$, corrected for sample lost during volatilisation), which is somewhat lower than expected for formation of $\mathrm{Bi}_{2} \mathrm{O}_{3}(55.1 \%$ mass loss would equate to the formation of $\mathrm{Bi}_{2} \mathrm{O}_{3}$ ), although whether this is due to incomplete precursor decomposition or additional precursor evaporation is unclear, with XRD analysis of the TGA residue not revealing any peaks not 15 assigned to $\mathrm{Bi}_{2} \mathrm{O}_{3}$.

The TGA data of $\left[\mathrm{Bi}(\text { thd })_{3}\right]$ shows a negligible weight loss $(1.5 \%)$ up to the melt at $113{ }^{\circ} \mathrm{C}$ (observed in the DSC trace), possibly due to residual moisture or solvent molecules, and may be ignored. Between $113{ }^{\circ} \mathrm{C}$ and $195{ }^{\circ} \mathrm{C}$ there is loss of $7.5 \%$ of mass, which coincides with the observation of an endotherm in the DSC (not shown) at $113{ }^{\circ} \mathrm{C}$ (assigned as the melt) and this is therefore ascribed to volatilisation of the precursor. This is 20 followed by two separate weight loss steps of $26.6 \%$ by $246{ }^{\circ} \mathrm{C}$ and $46.3 \%$ to $600{ }^{\circ} \mathrm{C}$, which coincide with 
exotherms in the DSC (not shown) and are therefore due to precursor decomposition. The fraction of weight loss ascribed to precursor decomposition is 80\% ( 73\% mass loss from a total mass of $91 \%$ after precursor evaporation), which is not consistent with the formation of $\mathrm{Bi}_{2} \mathrm{O}_{3}$ only, which requires a mass loss of $69.3 \%$. This additional weight loss may be due to decomposition to metallic bismuth or a suboxide, however the XRD 5 pattern of the residue was complex and neither species could be confirmed from the data.

The TGA data of $\left[\mathrm{Bi}\left(\mathrm{O}^{t} \mathrm{Bu}\right)_{3}\right]$ shows negligible weight loss $(1.70 \%)$ up to $189^{\circ} \mathrm{C}$, with an endotherm observed in the DSC trace (not shown) assigned as the melt, hence this weight loss is most likely to volatilisation of the precursor. There then follows a weight loss of $11.0 \%$ to $197{ }^{\circ} \mathrm{C}$, which is conincident with an exotherm in the DSC, hence indicating partial decomposition. A second weight loss step of $32.8 \%$ to $318{ }^{\circ} \mathrm{C}$ is also observed, 10 again coincident with exotherms in the DSC, indicative of decomposition. The fraction of weight loss during precursor decomposition is $\sim 45 \%$ ( 44\% weight loss from a total mass of $98 \%$ after precursor evaporation), which is consistent with the formation of $\mathrm{Bi}_{2} \mathrm{O}_{3}$ (theoretical mass loss for $\mathrm{Bi}_{2} \mathrm{O}_{3}$ is $45.7 \%$ ). During the preparation of this paper TGA data of $\left[\mathrm{Bi}\left(\mathrm{O}^{t} \mathrm{Bu}\right)_{3}\right]$ was released by researchers investigating the use of this precursor for ALD. ${ }^{18}$ In their analysis, when using similar sealed pans to our experiments, they observed thermal 15 decomposition of the precursor by $270{ }^{\circ} \mathrm{C}$, which is consistent with the data reported here allowing for differences in experimental parameters.

Analysis of the decomposition pathways of the three precursors using analysis of the mass loss fragments during each decomposition step and TGA-coupled mass spectrometry did not yield conclusive results with respect to individual precursor decomposition pathways, and as noted XRD analysis of residues was inconclusive, and

20 therefore we are unable to speculate on the cause of the incomplete and excess mass loss in $\left[\mathrm{Bi}(\mathrm{mmp})_{3}\right]$ and $\left[\mathrm{Bi}(\text { thd })_{3}\right]$ respectively compared to $\left[\mathrm{Bi}\left(\mathrm{O}^{t} \mathrm{Bu}\right)_{3}\right]$.

Another important property of a CVD precursor is volatility and the vapour pressures of $\left[\mathrm{Bi}(\text { thd })_{3}\right],\left[\mathrm{Bi}\left(\mathrm{O}{ }^{t} \mathrm{Bu}\right)_{3}\right]$ and $\left[\mathrm{Bi}(\mathrm{mmp})_{3}\right]$ were plotted using vapour pressure equations from the literature (Figure 2). ${ }^{25,26}$ 


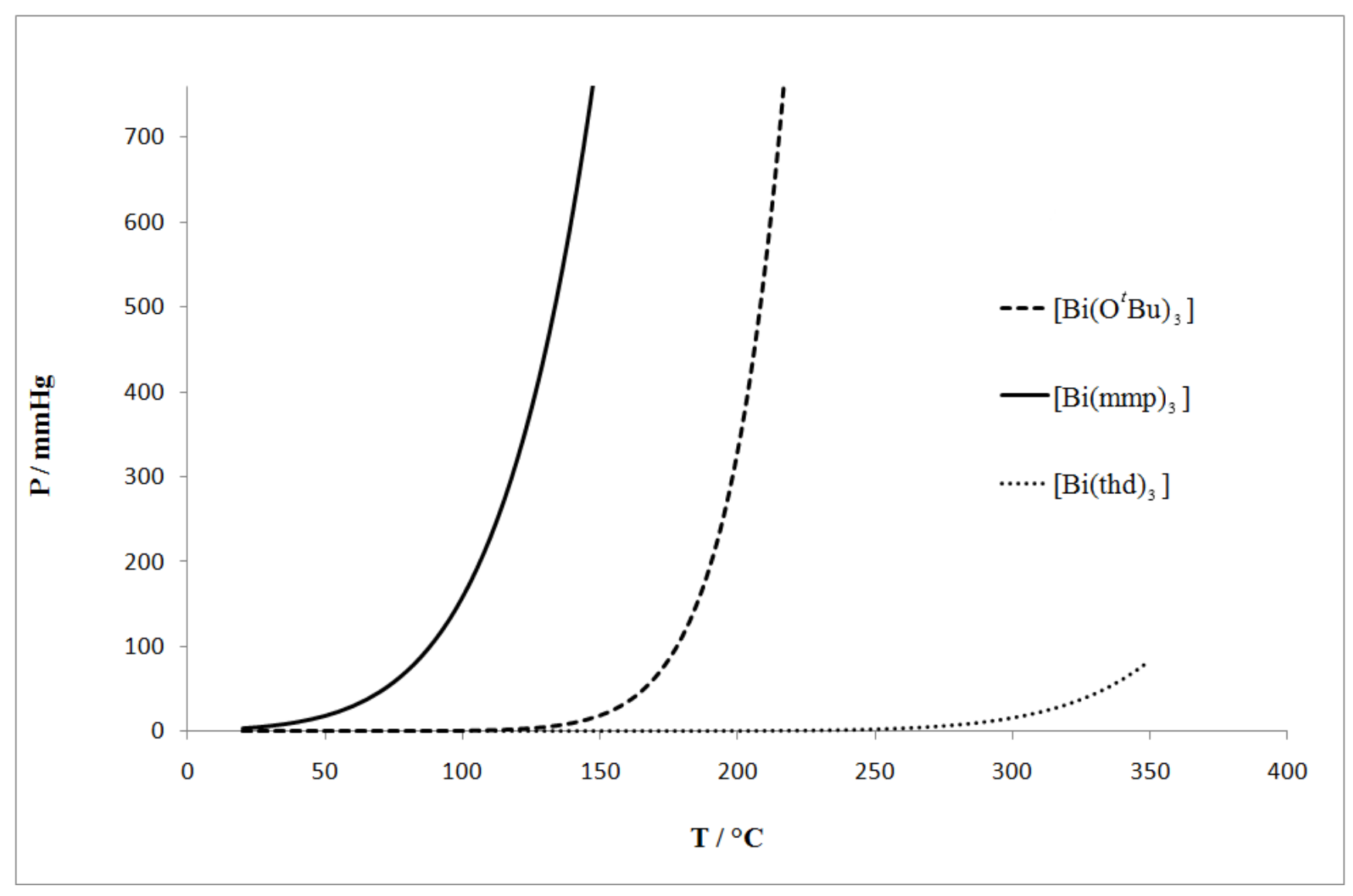

Figure 2 - Vapour pressure curves for $\left[\mathrm{Bi}(\text { thd })_{3}\right],\left[\mathrm{Bi}\left(\mathrm{O}^{t} \mathrm{Bu}\right)_{3}\right]$ and $\left[\mathrm{Bi}(\mathrm{mmp})_{3}\right]$

$\left[\mathrm{Bi}(\mathrm{mmp})_{3}\right]$ exhibits a relatively high vapour pressure of $158 \mathrm{mmHg}$ at $100{ }^{\circ} \mathrm{C}$ and this correlates with the 5 relatively large mass loss of the precursor $(\sim 18 \%)$ observed in the TGA prior to the onset of decomposition, ascribed to volatilisation. The vapour pressure of $\left[\mathrm{Bi}\left(\mathrm{O}^{t} \mathrm{Bu}\right)_{3}\right]$ at this temperature is $0.48 \mathrm{mmHg}$, and is negligible $\left(2.15 \times 10^{-4} \mathrm{mmHg}\right)$ for $\left[\mathrm{Bi}(\mathrm{thd})_{3}\right]$, which is somewhat surprising given the observed mass loss of $7.5 \%$ for the $\left[\mathrm{Bi}(\text { thd })_{3}\right]$ precursor ascribed to precursor evaporation during TGA analysis. Despite its low vapour pressure, $\left[\mathrm{Bi}(\text { thd })_{3}\right]$ has been successfully employed as a precursor to $\mathrm{Bi}_{2} \mathrm{O}_{3}$ films via DLI-CVD, ${ }^{19}$ a technique 10 which would assist in overcoming the poor volatility and decomposition characteristics of this precursor.

$\left[\mathrm{Bi}\left(\mathrm{O}^{t} \mathrm{Bu}\right)_{3}\right]$ exhibits an appreciable vapour pressure that is significantly higher than $\left[\mathrm{Bi}(\text { thd })_{3}\right]$ and possesses excellent decomposition characteristics for formation of $\mathrm{Bi}_{2} \mathrm{O}_{3}$, as assessed using TGA, and was therefore selected as the precursor of choice for this study.

\section{CVD}

15 The use of $\left[\mathrm{Bi}\left(\mathrm{O}^{t} \mathrm{Bu}\right)_{3}\right]$ as a single-source precursor to transparent gold/yellow crystalline bismuth oxide thin films was studied over a variety of substrate temperatures (no deposition was obtained below $425{ }^{\circ} \mathrm{C}$ ), system pressures and carrier gas flow rates. Despite reported decomposition problems encountered when using this precursor for $\mathrm{ALD},{ }^{18}$ we did not observe detrimental precursor decomposition when maintaining a bubbler temperature of $110{ }^{\circ} \mathrm{C}$. All films displayed good substrate coverage and were adherent; all films passed the 
Scotch tape test but did not survive after treatment with steel wool. The films did not show any changes in characteristics after prolonged storage in air. The CVD growth conditions are shown in Table 1.

Table 1 - Details of the CVD experiments

\begin{tabular}{|c|c|c|c|c|c|}
\hline $\begin{array}{l}\text { Substrate temp } \\
\qquad /{ }^{\circ} \mathrm{C}\end{array}$ & $\begin{array}{l}\text { Nitrogen flow } \\
\text { rate } \\
\text { / ccm }\end{array}$ & $\begin{array}{c}\text { System } \\
\text { pressure } \\
\text { / mbar }\end{array}$ & $\begin{array}{l}\text { Crystalline } \\
\text { phase(s) }\end{array}$ & $\begin{array}{l}\text { Film thickness / } \\
\mathrm{nm}\end{array}$ & Bandgap / eV \\
\hline 425 & 12 & 8 & $\beta$ & 75 & 2.4 \\
\hline 450 & 12 & 8 & $\beta, \gamma$ & 302 & 2.3 \\
\hline 475 & 12 & 8 & $\beta, \gamma$ & 328 & 2.3 \\
\hline 500 & 12 & 8 & $\gamma$ & 515 & 2.8 \\
\hline 450 & 12 & 15 & $\beta, \gamma$ & 187 & 2.5 \\
\hline 450 & 12 & 20 & $\beta, \gamma$ & 294 & 2.6 \\
\hline 450 & 12 & 45 & $\alpha, \gamma$ & 526 & 2.8 \\
\hline 450 & 20 & 8 & $\gamma$ & & 2.9 \\
\hline 450 & 25 & 8 & $\gamma$ & & 2.7 \\
\hline 450 & 40 & 8 & $\gamma$ & & 3.0 \\
\hline
\end{tabular}

5

$\mathrm{X}$-ray diffraction patterns revealed the presence of crystalline, mixed phase films, composed of $\beta$ - and $\gamma$ - phases. At $500{ }^{\circ} \mathrm{C}$, the $\gamma$ - phase was the predominant crystalline phase (Figure 3) and this was also the dominant phase upon increasing the carrier gas flow rate from 12 to $40 \mathrm{~cm}^{3} / \mathrm{min}$ at $450{ }^{\circ} \mathrm{C}$. 


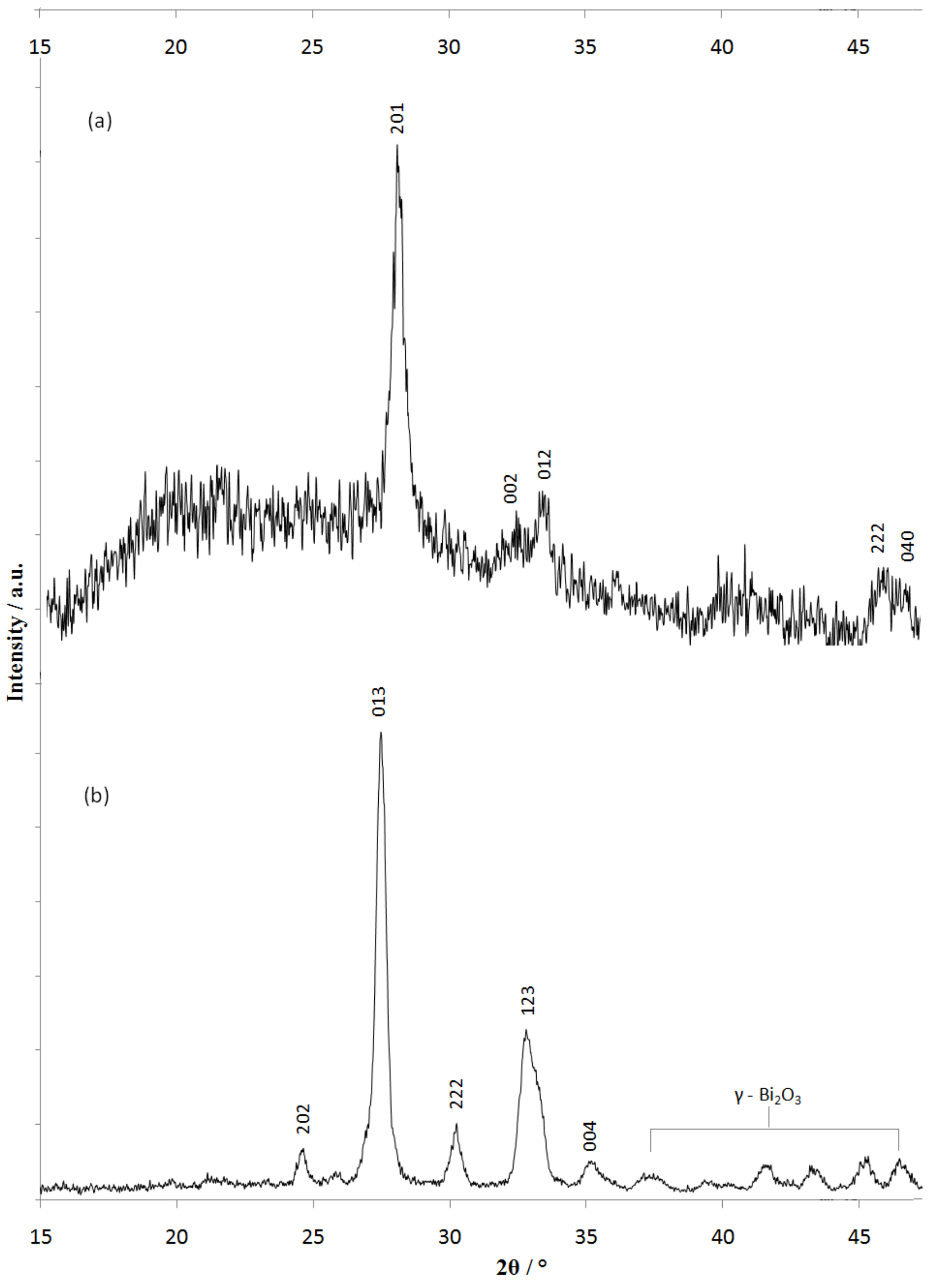

Figure 3-X-Ray diffraction patterns of (a) $\beta-\mathrm{Bi}_{2} \mathrm{O}_{3}$ and (b) $\gamma-\mathrm{Bi}_{2} \mathrm{O}_{3}$, low intensity peaks not indexed 
Unit cell dimensions of $a=b=c=10.27$ (3) $\AA$ obtained for the $\gamma$-phase were in agreement with literature values $\left(a=b=c=10.25 \AA\right.$ ).${ }^{27}$ At $425{ }^{\circ} \mathrm{C}(8$ mbar $)$, the $\beta$ - phase was the dominant crystalline species with unit cell dimensions of $a=b=7.8$ (1) $\AA, c=5.7$ (2) $\AA$ for the $\beta$ - phase in agreement with literature values $(a=b=$ $57.738 \AA, c=5.731 \AA$ ),${ }^{27}$ and films deposited at 450 and $475{ }^{\circ} \mathrm{C}$ resulted in mixed $\beta$ - and $\gamma$ - phases. At a carrier gas flow rate of $45 \mathrm{~cm}^{3} /$ min a mixed $\alpha$ - and $\beta$ - phase was observed. Similar variations in crystalline phases obtained via MOCVD of $\mathrm{Bi}_{2} \mathrm{O}_{3}$ were also observed by Tondello ${ }^{12}$ using triphenylbismuth in a dual-source reaction with oxygen.

Film thickness data were obtained using side-on SEM imaging. As expected, the film growth rate increased as a 10 function of substrate temperature (Figure 4), and also as a function of carrier gas flow rate.

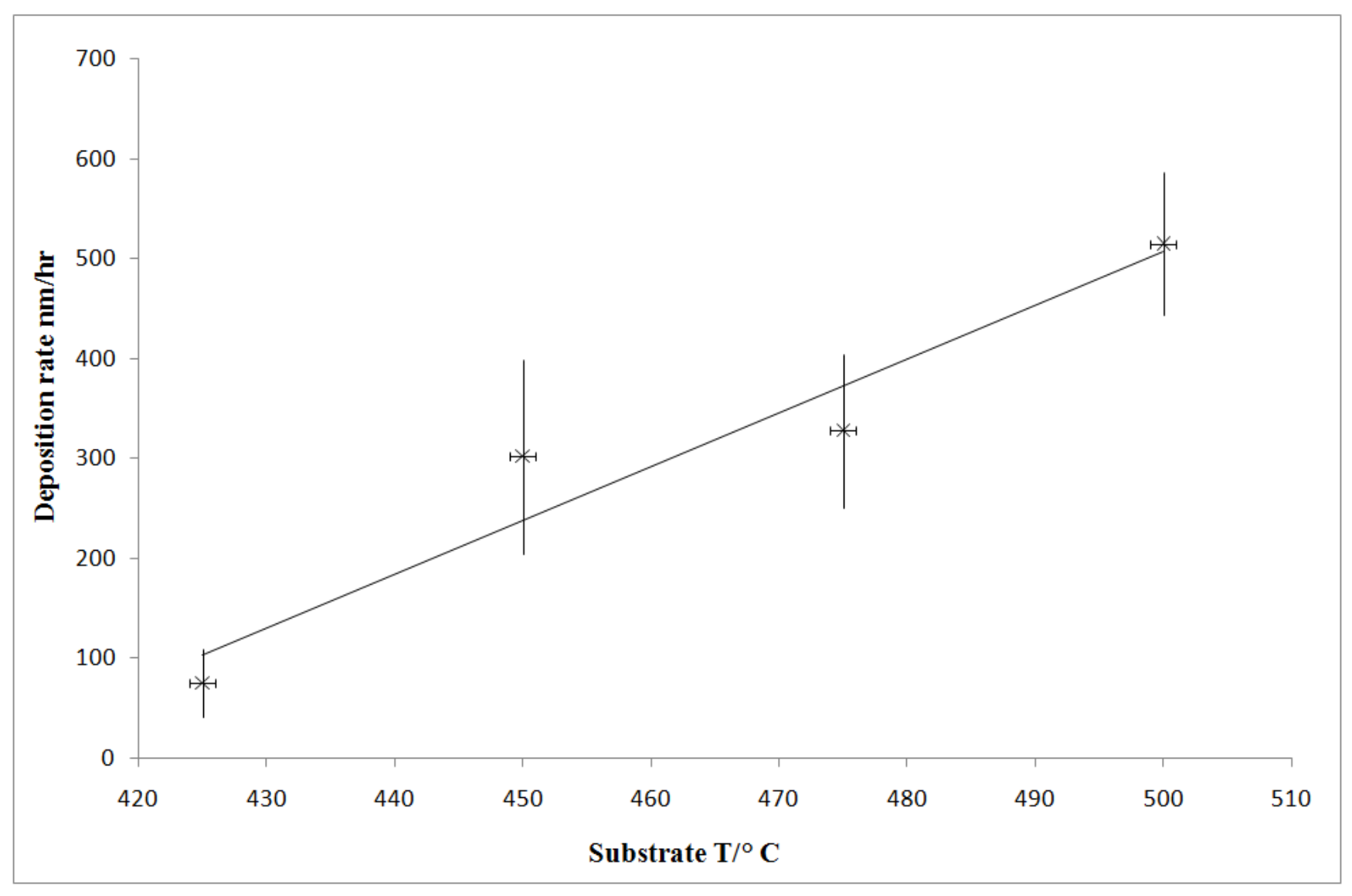

Figure 4 - Film growth rates as a function of substrate temperature

15 In comparison to the use of $\left[\mathrm{Bi}(\mathrm{mmp})_{3}\right]$ as a bismuth oxide precursor, ${ }^{17}$ we did not observe constant/fixed film growth rates as a function of substrate temperature. The film thickness at substrate temperatures of $425{ }^{\circ} \mathrm{C}$ was approximately $75 \mathrm{~nm}$, and at $500{ }^{\circ} \mathrm{C}$ approximately $520 \mathrm{~nm}$. The deposition rates were therefore ca. $75 \mathrm{~nm}, 302$ $\mathrm{nm}, 328 \mathrm{~nm}$ and $515 \mathrm{~nm} \mathrm{hr}^{-1}$ at substrate temperatures of $425,450,475$ and $500{ }^{\circ} \mathrm{C}$ respectively. Typically all deposited films demonstrated good substrate coverage and uniformity. 
The top-down SEM micrographs of the deposited bismuth oxide films displayed a variety of morphologies according to temperature (Figure 5).
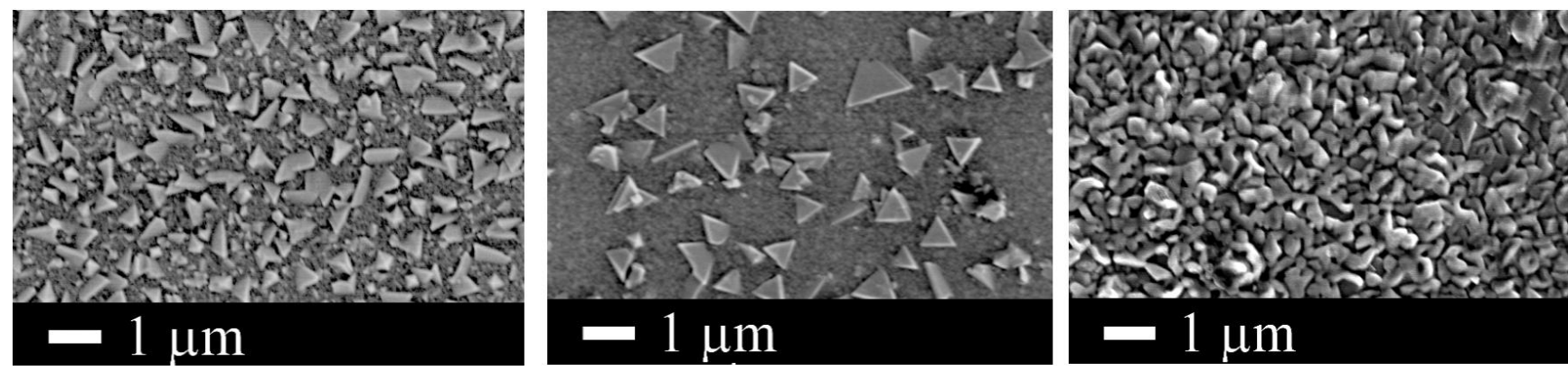

5 Fig. 5- Scanning electron micrographs of $\mathrm{Bi}_{2} \mathrm{O}_{3}$ films deposited via LPCVD of $\left[\mathrm{Bi}\left(\mathrm{O}^{t} \mathrm{Bu}\right)_{3}\right]$ at $425^{\circ} \mathrm{C}(\mathrm{left}), 475$ ${ }^{\circ} \mathrm{C}$ (centre), and $500{ }^{\circ} \mathrm{C}$ (right).

Crystallites of varying size $(0.4-2 \mu \mathrm{m})$ are clearly observed in the SEM images, with profound triangular facets apparent in films deposited at $425^{\circ} \mathrm{C}$ and $475^{\circ} \mathrm{C}$, and these facets are better defined at the higher temperature. 10 The film growth appeared to be non-uniform, particularly at $475{ }^{\circ} \mathrm{C}$, however the film deposited at $500{ }^{\circ} \mathrm{C}$ displayed increased uniformity with the grains appearing to have coalesced. The optical properties of the deposited $\mathrm{Bi}_{2} \mathrm{O}_{3}$ films were measured using $\mathrm{UV}$-vis spectroscopy in transmission mode. The band gap values obtained via Tauc plots ${ }^{28}$ appear to be in general agreement with other bismuth oxide band gap values derived from similar experiments. ${ }^{9,29}$ The band gap values of films possessing the $\beta$ - phase as the dominant phase are in 15 the range $2.2-2.4 \mathrm{eV}$, with those predominantly $\gamma$ - phase displaying band gaps between $2.7-3.0 \mathrm{eV}$ and are in agreement with the literature. ${ }^{10,30,31,39}$ The films described as mixed $\beta$ - and $\gamma$-phase possessed band gaps in the region $2.3-2.6 \mathrm{eV}$.

Raman spectra were recorded for all of the bismuth oxide films grown via LPCVD of $\left[\mathrm{Bi}\left(\mathrm{O}^{t} \mathrm{Bu}\right)_{3}\right]$. The predominantly $\beta-\mathrm{Bi}_{2} \mathrm{O}_{3}$ films exhibited few distinguishable features in the Raman spectrum. Broad peaks at 372 $20 \mathrm{~cm}^{-1}$ and $580 \mathrm{~cm}^{-1}$ were the only two peaks observed with a relatively largebackground signal due to breakthrough to the substrate in these thin films. The Raman spectra of the predominantly $\gamma-\mathrm{Bi}_{2} \mathrm{O}_{3}$ film deposited at $500{ }^{\circ} \mathrm{C}$ (Figure 6) displayed peaks at 533, 452, 319, 279, 211, 154, 141 and $125 \mathrm{~cm}^{-1}$ which were identical to reported Raman spectra of the metal cation stabilised sillenite structures $\mathrm{Bi}_{12}\left(\mathrm{Bi}_{0.53} \mathrm{Mn}_{0.47}\right) \mathrm{O}_{20}$ and $\mathrm{Bi}_{12} \mathrm{SiO}_{20}{ }^{32}$ and $\mathrm{Bi}_{12} \mathrm{TiO}_{20}$, ${ }^{33}$ the structures of which are all body-centred cubic and may be represented 25 parentally by $\gamma-\mathrm{Bi}_{2} \mathrm{O}_{3}$ with general structure $\mathrm{Bi}_{12}\left(\mathrm{Bi}_{4 / 5-\mathrm{n} / \mathrm{x}} \mathrm{M}^{\mathrm{n}+}{ }_{5 \mathrm{x}}\right) \mathrm{O}_{19.2+\mathrm{nx}},{ }^{34}$ however the peak at $185 \mathrm{~cm}^{-1}$ (Figure 6) remains unassigned. 


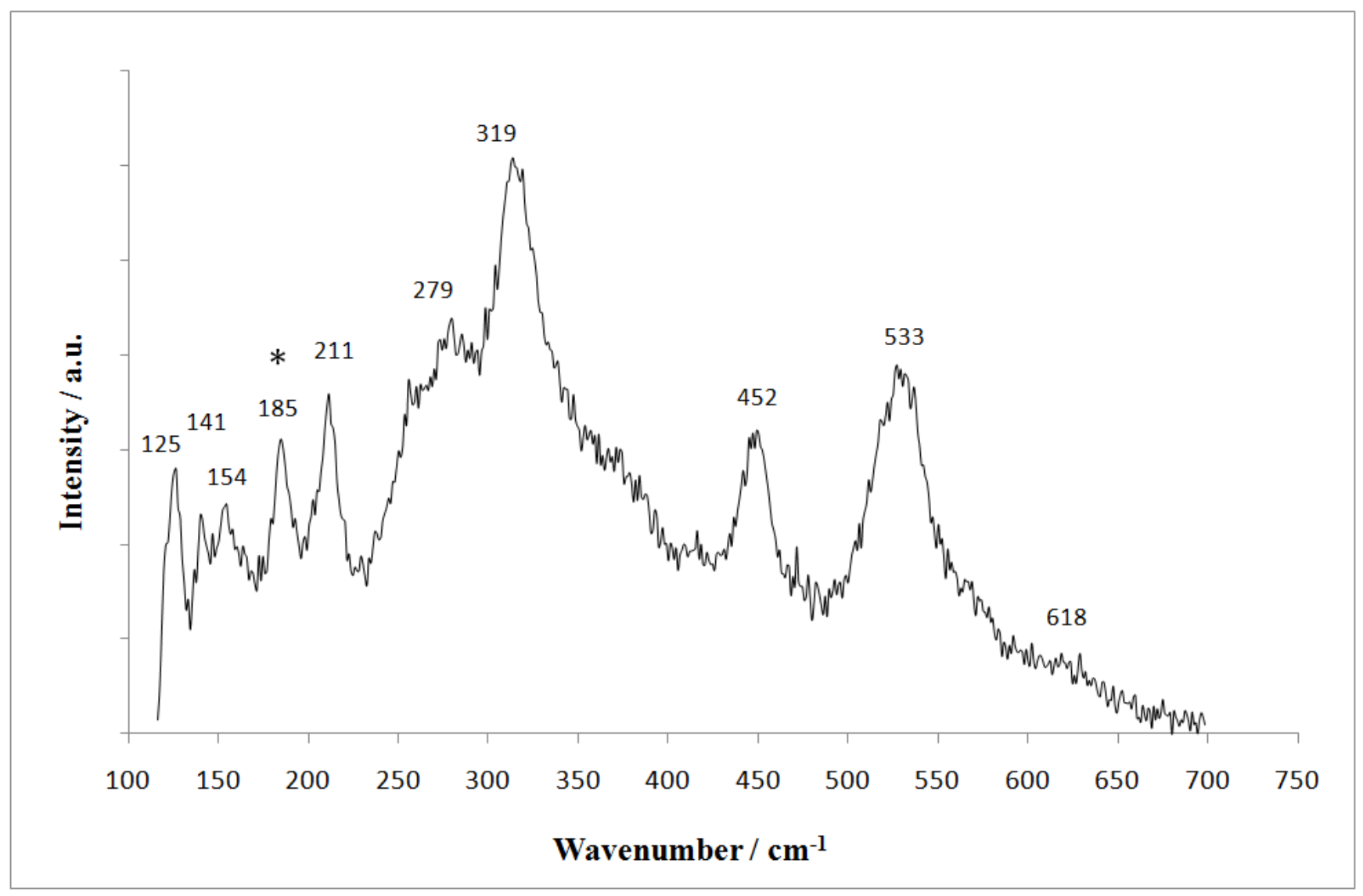

Fig. 6- Raman spectrum for the predominantly $\gamma-\mathrm{Bi}_{2} \mathrm{O}_{3}$ film deposited at $500{ }^{\circ} \mathrm{C}$

The compositions of the as-deposited films were studied using X-ray Photoelectron Spectroscopy (XPS). The 5 bismuth $4 \mathrm{f}$ surface ionisation displayed one principle environment, with the $\mathrm{Bi} 4 \mathrm{f}_{7 / 2}$ peak observed at $158.8 \mathrm{eV}$ for all films, characteristic of $\mathrm{Bi}_{2} \mathrm{O}_{3}{ }^{35}$ The $\mathrm{O} 1 \mathrm{~s}$ ionisation was observed between $529.7-529.8 \mathrm{eV}$, and such a position is characteristic of oxygen bound to bismuth in $\mathrm{Bi}_{2} \mathrm{O}_{3} \cdot{ }^{35}$ Bismuth to oxygen ratios close to $\mathrm{Bi}_{2} \mathrm{O}_{3}$ were observed for all films in the range 1.3 - 1.6 oxygen atoms to bismuth with oxygen deficient stoichiometries found for films deposited at $425{ }^{\circ} \mathrm{C}(1.4), 450{ }^{\circ} \mathrm{C}(1.4)$ and $500{ }^{\circ} \mathrm{C}(1.3)$. This is similar to reported XPS data ${ }^{12}$ 10 of $\beta-\mathrm{Bi}_{2} \mathrm{O}_{3}$ thin films, ascribed to the formation of oxygen-deficient $\beta-\mathrm{Bi}_{2} \mathrm{O}_{3-\mathrm{x}}$ as a result of oxygen vacancies found in the lattice. Etching experiments were carried out, however this resulted in preferential sputtering of lighter atoms, and exact bismuth and oxygen compositions could not be determined after etching. Carbon decreased dramatically after etching, suggesting that the carbon on the film surface is due to adventitious carbon contamination; however quantification in the bulk was not possible due to extreme distortion of the bismuth 15 peak after etching.

Films deposited at $475{ }^{\circ} \mathrm{C}$ (band gap $2.3 \mathrm{eV}$ ) and $500{ }^{\circ} \mathrm{C}$ (band gap $2.8 \mathrm{eV}$ ) were chosen for an investigation into their water degradation properties under UV-light, the experimental details of which are described elsewhere. ${ }^{36}$ In addition to the two $\mathrm{Bi}_{2} \mathrm{O}_{3}$ films, an uncoated borosilicate glass substrate was tested and used as a reference. After suspending each sample in the oxygen electrode chamber (consisting of a $0.1 \mathrm{M} \mathrm{KOH}$ and $200.01 \mathrm{M} \mathrm{Na}_{2} \mathrm{~S}_{2} \mathrm{O}_{8}$ solution previously purged with oxygen-free nitrogen), the sample was enclosed in the chamber 
and irradiated with a $16 \mathrm{~W}, 365 \mathrm{~nm}$ UV-light for 1800 seconds from a distance of $50 \mathrm{~mm}$. The generated dissolved oxygen concentration was plotted as a function of time, and the rate of oxygen production determined from the gradient of these plots (Table 2).

5 Table 2 - Summary of the individual film properties and the rate of oxygen production for the two films chosen

\begin{tabular}{|c|c|c|c|}
\hline Substrate temp $/{ }^{\circ} \mathrm{C}$ & Film Thickness / nm & Bandgap / eV & $\begin{array}{c}\text { Rate of } \mathrm{O}_{2} \text { production } / \\
\mu \mathrm{mol} / \mathrm{hr}\end{array}$ \\
\hline 475 & 328 & 2.3 & 0.44 \\
\hline 500 & 515 & 2.8 & 1.1 \\
\hline Uncoated Glass & - & - & 0 \\
\hline
\end{tabular}

Appreciable oxygen evolution was observed in the presence of UV-light for two samples of undoped $\mathrm{Bi}_{2} \mathrm{O}_{3}$ thin films, formed via LPCVD of $\left[\mathrm{Bi}\left(\mathrm{O}^{t} \mathrm{Bu}\right)_{3}\right]$, whereas the substrate-only experiment, which acted as a reference, exhibited zero oxygen production as expected.

10 Films deposited at $500{ }^{\circ} \mathrm{C}$, which were predominantly $\gamma$ - phase, resulted in 2.5 times the rate of oxygen evolution in comparison to films deposited at $475{ }^{\circ} \mathrm{C}$, which were mixed $\beta$ - and $\gamma$ - phase, despite the latter sample possessing a narrower bandgap of $2.3 \mathrm{eV}$ compared to $2.8 \mathrm{eV}$. The comparison of photocatalyst results obtained under different experimental conditions is notoriously difficult, as noted by Kudo and Miseki in their comprehensive review, ${ }^{37}$ however the results obtained here for the photo-oxidation of water are of the order of 15 those obtained from the use of optimised $\mathrm{TiO}_{2}$ (anatase) thin films on glass investigated using an identical experiment, that yielded oxygen evolution rates between $0.056-0.440 \mu \mathrm{mol} / \mathrm{hr} .{ }^{36} \mathrm{An}$ apparent quantum yield of 9.8\% (at $365 \mathrm{~nm}$ ) was calculated using Eqtn 1, which demonstrates these $\mathrm{Bi}_{2} \mathrm{O}_{3}$ films are at least as active as a range of oxide photocatalysts. ${ }^{37}$

Apparent Quantum Yield $\left(\Phi_{\mathrm{O}_{2}}\right)=\frac{4 \times \mathrm{O}_{2} \text { rate }(\mu \mathrm{mol} / \mathrm{hr})}{\text { photon rate }(\mu \text { Einsteins } / \mathrm{hr})}$

This appears to be the first investigation into the water photodegradation properties of undoped $\mathrm{Bi}_{2} \mathrm{O}_{3}$ thin films 20 synthesised by chemical vapour deposition. The hydrogen production from visible-light photocatalytic splitting of water has already been reported using bulk $\gamma-\mathrm{Bi}_{2} \mathrm{O}_{3}$ on $\mathrm{Pt} / \mathrm{RuO}_{2}\left(\Phi_{\mathrm{H}_{2}}=1.1 \%\right)^{38}$ and when using transition metal ion-doped $\gamma-\mathrm{Bi}_{2} \mathrm{O}_{3}\left(\Phi_{\mathrm{H}_{2}}=1.3 \%\right){ }^{39}$ Recent work ${ }^{40}$ has shown that Pt-doped bulk $\alpha-\mathrm{Bi}_{2} \mathrm{O}_{3}$ is able to degrade organic pollutants under visible light, so the potential for $\mathrm{Bi}_{2} \mathrm{O}_{3}$ induced photocatalysis is encouraging. 
$\left[\mathrm{Bi}\left(\mathrm{O}^{t} \mathrm{Bu}\right)_{3}\right]$ has proved to be an excellent single-source precursor for MOCVD of crystalline $\mathrm{Bi}_{2} \mathrm{O}_{3}$ films at a variety of substrate temperatures, system pressures and carrier gas flow rates, with the relatively low bubbler temperatures required to transport the precursor through the system and clean decomposition to $\mathrm{Bi}_{2} \mathrm{O}_{3}$ giving it a distinct advantage over other commonly used bismuth precursors. The films consisted of variable mixtures of

$5 \beta$ - and $\gamma$ - phases, but under particular conditions, the $\beta$ - or $\gamma$ - phases could be grown preferentially. All films possessed band gaps between $2.3-3.0 \mathrm{eV}$ dependent upon the phase present. Top-down SEM imaging generally revealed an island-type growth mechanism with morphology varying with temperature. Film thickness increased with respect to substrate temperature and total system pressure. XPS conducted on the films chosen revealed an approximate 2:3 ratio of $\mathrm{Bi}: \mathrm{O}$, with carbon contamination decreasing dramatically upon

10 etching. We have also demonstrated the use of these films for UV-light induced photodegradation of water into oxygen.

\section{Acknowledgements}

The EPSRC and UCL are thanked for a Studentship (SM). The Ramsay Memorial Fund is thanked for a 15 Fellowship (GH). Thanks go to Dr S. Firth for assistance with DSC and Raman experiments, and to Mr K. Reeves for assistance with SEM measurements. Dr Emily Smith (University of Nottingham) is thanked for carrying out XPS analysis under EPSRC grant EP/F019750/1: "A Coordinated Open-Access Centre for Comprehensive Materials Analysis."

\section{References}

1 B. H. Park, B. S. Kang, S. D. Bu, T. W. Noh, J. Lee and W. Jo, Nature, 1999, 401, 682

2 J. Wang, J. B. Neaton, H. Zheng, V. Nagarajan, S. B. Ogale, B. Liu, D. Viehland, V. Vaithyanathan, D. G. Schlom, U. V. Waghmare, N. A. Spaldin, K. M. Rabe, M. Wuttig and R. Ramesh, Science, 2003, 299, 1719

3 M. K. Singh, Y. Yang and C. G. Takoudis, Coord. Chem. Rev., 2009, 253, 2920

4 C. Michel, M. Hervieu, M. M. Borel, A. Grandin, F. Deslandes, J. Provost and B. Raveau, Z. Physik B Condensed Matter, 1987, 68, 421

5 A. M. Azad, S. Larose and S. A. Akbar, J. Mater. Sci., 1994, 29, 4135

6 G. S. Devi, S. V. Manorama and V. J. Rao, Sens. Actuators B-Chemical, 1999, 56, 98

7 H. Heidong, Q. Wei,W. Xiaohong, D. Xianbo, C. Long and J. Zhaohua, Thin Solid Films, 2007, 515, 5362

8 K. Gurunathan, Int. J. Hydrogen Energy, 2004, 29, 933

9 L. Leontie, M. Caraman, M. Alexe and C. Harnagea, Surf. Sci., 2002, 507, 480 
${ }^{10}$ L. Zhou, W. Wang, H. Xu, S. Sun and M. Shang, Chemistry - A European Journal, 2009, 15, 1776

${ }^{11}$ L. Zhang, W. Wang, J. Yang, Z. Chen, W. Zhang, L. Zhou and S. Liu, Appl. Catalysis A: General, 2006, 308, 105

${ }^{12}$ G. Bandoli, D. Barreca, E. Brescacin, G. A. Rizzi and E. Tondello, Chem. Vap. Deposition, 1996, 2, 238

${ }^{13}$ C. Bedoya, G. G. Condorelli, G. Anastasi, A. Baeri, F. Scerra, I. L. Fragala, J. G. Lisoni and D. Wouters, Chem. Mater., 2004, 16, 3176

${ }^{14}$ C. Bedoya, G. Condorelli, S. T. Finocchiaro, A. DiMauro, I. L. Fragala, L. Cattaneo and S. Carella, Chem. Vap. Deposition, 2005, 11, 261

15 H. W. Kim, J. H. Myung and S. H. Shim, Solid State Comm., 2006, 137, 196

16 H. W. Kim, J. H. Myung, S. H. Shim and C. Lee, Appl. Phys. A 2006, 84, 187

${ }^{17}$ P. A. Williams, A. C. Jones, M. J. Crosbie.; P. J. Wright, J. F. Bickley, A. Steiner, H. O. Davies, T. J. Leedham and G. W. Critchlow, Chem. Vap. Deposition, 2001, 7, 205

18 T. Hatanpaa, M. Vehkamaki, M. Ritala and M. Leskela, Dalton Trans., 2010, 39, 3219

19 S. W. Kang and S. W. Rhee, Thin Solid Films, 2004, 468, 79

20 M. Vehkamaki, T. Hatanpaa, M. Ritala and M. Leskala,. J. Mater. Chem., 2004, 14, 3191

${ }^{21}$ A. Haaland, H. P. Verne, H. V. Volden, R. Papiernik and L. G. Hubert-Pfalzgraf, Acta. Chem. Scand., 1993, 47, 1043

${ }^{22}$ C. S. Blackman, C. J. Carmalt, S. J. A. Moniz, S. E. Potts, H. O. Davies and D. Pugh, ECS Trans., 2009, 25, 561

${ }^{23}$ M. C. Massiani, R. Papiernik, L. G. Hubert-Pfalzgraf and J-C Daran, Polyhedron, 1991, 10, 437

24 W. A. Hermann, N. W. Huber, R. Anwander and T. Priermeier, Chem. Ber., 1993, 126, 1127

25 SAFC Hitech Ltd. Product Catalogue 2008, accessed 15 March 2010:

http://www.safcglobal.com/etc/medialib/docs/SAFC/Bulletin/product-catalogue-2008.pdf

${ }^{26}$ Y. Kojima, H. Kadokura, Y. Okuhara, M. Matsumoto and T. Mogi, Integrated Ferroelectrics, 1997, 18, 183

27 H. A. Harwig, Z. Anorg. Allg. Chemie, 1978, 444, 151

28 J. Tauc, R. Grigorovici and A. Vancu, physica status solidi (b)., 1966, 15, 627

29 V. Dolocan, Appl. Phys., 1978, 16, 405 
30 B. L. Zhu and X. Z. Zhao, Opt. Mater., 2006, 29, 192

${ }^{31}$ P. Maruthamuthu, K. Gurunathan, E. Subramanian and M. V. C. Shastri, Int. J. Hydrogen Energy, 1993, 18, 9

32 B. Mihailova, M. Gospodinov and L. Konstantinov, J. Phys. Chem. Sol., 1999, 60, 1821

33 B. Mihailova, G. Bogachev, V. Marinova and L. Konstantinov, J. Phys. Chem. Sol., 1999, 60, 1829

34 M. Valant and D. Suvorov, Chem. Mater., 2002, 14, 3471

35 V. S. Dharmadhikari, J. Electron Spec., 1982, 25, 181

${ }^{36}$ G. Hyett, J. A. Darr, A. Mills and I. P. Parkin, Chemistry - A European Journal, 2010, accepted for publication

37 A. Kudo, Y. Miseki, Chem. Soc. Rev., 2009, 38, 252

${ }^{38}$ P. Maruthamuthu, K. Gurunathan, E. Subramanian and M. V. C. Shastri, Int. J. Hydrogen Energy, 1994, 19, 889

39 K. Gurunathan, Int. J. Hydrogen Energy, 2004, 29, 933

40 R. Li, W. Chen, H. Kobayashi and C. Ma, Green Chem., 2010, 12, 212 